Ecological Applications, v.11, iss. 3, 2001, p.731-746.

http://esapubs.org/

http://www.esajournals.org/loi/ecap

ISSN: 1051-0761

doi: 10.1890/1051-0761(2001)011[0731:LADILE]2.0.CO;2

(C) 2001 by the Ecological Society of America.

\title{
LIFE AFTER DEATH IN LAKE ERIE: NUTRIENT CONTROLS DRIVE FISH SPECIES RICHNESS, REHABILITATION
}

\author{
Stuart A. Ludsin, Mark W. Kershner, Karen A. Blocksom, Roger L. Knight*, and Roy A. Stein
}

Aquatic Ecology Laboratory, Department of Evolution, Ecology, and Organismal Biology, Ohio State University.

*Sandusky Fisheries Research Unit, Ohio Department of Natural Resources-Division of Wildlife.

\begin{abstract}
We explored the recent (1969-1996) dynamics of fish communities within Lake Erie, a system formerly degraded by eutrophication and now undergoing oligotrophication owing to phosphorus abatement programs. By merging bottom trawl data from two lake basins of contrasting productivity with life-history information (i.e., tolerances to environmental degradation, diet and temperature preferences), we examined (1) the relationship between system productivity and species richness, (2) whether fish communities are resilient to eutrophication, and (3) whether oligotrophication necessarily leads to reduced sport and commercial fish production. Reduced phosphorus loading has led to fish community rehabilitation. In the productive west basin, six species tolerant of eutrophy (i.e., anoxia, turbidity) declined in abundance, whereas the abundance of three intolerant species increased through time. In the less productive central basin, although only one tolerant species declined, four species intolerant of eutrophic conditions recovered with oligotrophication. These differential responses appear to derive from dissimilar mechanisms by which reduced productivity alters habitat and resource availability for fishes. Specifically, enhanced bottom oxygen, combined with reduced biogenic turbidity and sedimentation, likely drove the loss of tolerant species in the west basin by reducing detrital mass or the ability of these species to compete with intolerant species under conditions of improved water clarity. In contrast, reduced bottom anoxia, which enhanced availability of cool- and cold-water habitat and benthic macroinvertebrate communities, appears important to the recovery of intolerant species in the central basin. Ultimately, these productivity-induced shifts caused species richness to decline in Lake Erie's west basin and to increase in its central basin. Beyond confirming that unimodal models of productivity and species diversity can describe fish community change in a recovering system, our results provide optimism in an otherwise dismal state of affairs in fisheries management (e.g., overexploitation), given that many recovering intolerant species are desired sport or commercial fishes.
\end{abstract}

\section{Introduction}

Understanding how communities are regulated has long been a goal of ecologists (McIntosh 1985). Through a vast number of field and experimental investigations, we have learned that many factors, including competition (e.g., Park 1948, Connell 1961), predation (e.g., Paine 1966, Lubchenco 1978), environmental (habitat) heterogeneity (e.g., Pianka 1967, Guegan et al. 1998), and disturbance (e.g., Hutchinson 1961, Sousa 1979), can structure both aquatic and terrestrial communities. Another regulatory factor that has received recent attention is system productivity, especially with regard to understanding species richness patterns (Rosenzweig and Abramsky 1993, Tilman and Pacala 1993, Huston 1994). In general, this body of work suggests that a unimodal relationship exists between productivity and species richness, wherein species richness increases at low levels of productivity, reaches a peak at intermediate levels, and declines as productivity becomes too high. Although this relationship has been well documented 
for plants (see Tilman and Pacala 1993) and invertebrates (see Rosenzweig and Abramsky 1993), and to a lesser extent for vertebrates (e.g., Abramsky and Rosenzweig 1984, Kay et al. 1997), the mechanisms underlying this relationship - particularly the reduction in species richness with increasing productivity — remain largely speculative (Rosenzweig and Abramsky 1993).

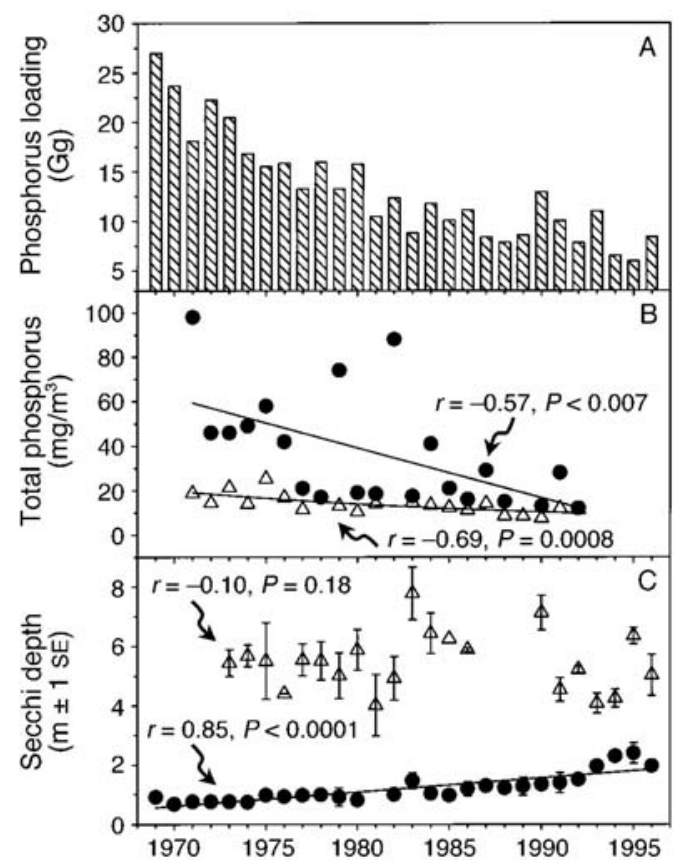

Fig. 1. (A) Lakewide phosphorus loading estimates for Lake Erie, 1969-1996. Estimates for 1969-1994 were taken from Gopalan et al. (1998); estimates for 1995 and 1996 were predicted from west basin Secchi depth data (univariate regression: $r^{2}=0.60, \mathrm{df}=26, P<0.0001$ ) because lakewide monitoring efforts ended in 1994. (B) Estimates of total water-column phosphorus for west (solid circles) and central (open triangles) Lake Erie (data source: Environmental Conservation Branch, Environment Canada and Great Lakes National Program Office, U.S. Environmental Protection Agency). (C) Mean July Secchi depth (i.e., water transparency) estimates for the west ( $n=$ 5 sites; solid circles) and central ( $n \geq 10$ sites; open triangles) basins of Lake Erie. ODNR-ODW provided west basin Secchi depth data, whereas central basin water transparency data were compiled from 1973-1982, Herdendorf (1983); 1983-1984 and 1990, Charlton et al. (1993); and 1991-1996, ODNR-ODW. Correlation coefficients $(r)$ and probability values $(P)$ were included for all trends, whereas regression lines were included only for significant trends $(\alpha=0.05)$.

Our inability to comprehend how productivity governs species richness (or any other community attribute) is problematic, especially for efforts aimed at conserving or managing our natural resources. For example, many north-temperate aquatic systems, historically subjected to eutrophication, now are undergoing oligotrophication, owing to nutrient abatement programs (Hartig et al. 1991, Dolan 1993, Sommer et al. 1993, Edmondson 1994, Ney 1996, Ruggiu et al. 1998, Van Der Molen 1998). We have a reasonable understanding of how lower trophic levels (e.g., phytoplankton, zooplankton, benthic macroinvertebrates) respond to both eutrophication (e.g., Carr and Hiltunen 1965, Patalas 1972, Leach et al. 1977, Laws 1981, Verdonschot 1996) and oligotrophication (e.g., Makarewicz and Bertram 1991, Makarewicz 1993a, b, Sommer et al. 1993, Edmondson 1994, Krieger et al. 1996, Lang and Reymond 1996, Ruggiu et al. 1998). However, we know little about how higher trophic levels (i.e., secondary and tertiary consumers, such as planktivorous and piscivorous fishes) react to reduced system productivity, even in the 
most intensively studied ecosystems (e.g., Lake Washington, USA; Lake Constance, AustriaGermany-Switzerland; Lake Erie, USA-Canada). Clearly, if we realistically expect to conserve biodiversity and manage our natural resources in a sustainable fashion, we must understand how productivity structures communities.

In this paper, we explore trends in fish species composition and richness in Lake Erie's west and central basins, two areas of contrasting productivity. We analyzed bottom trawl assessment data collected by the Ohio Department of Natural Resources-Division of Wildlife (ODNR-ODW) during 1969-1996, a period during which phosphorus abatement programs have caused Lake Erie to undergo oligotrophication. Because these data were collected at fixed sites through time, they offer an excellent opportunity to examine the dynamic nature of species succession within a vertebrate community. Ultimately, we relate our findings to aquatic resource management.

\section{Background}

Eutrophication in Lake Erie

Of the numerous anthropogenic impairments experienced by freshwater ecosystems during this century, none has been more ubiquitous than eutrophication (Naiman et al. 1995, Carpenter et al. 1998). Like other North American and European ecosystems, excessive phosphorus loading has dramatically altered the abiotic and biotic components of Lake Erie. By enhancing phytoplankton and zooplankton production, excessive phosphorus inputs ( $>20 \mathrm{Gg}$ annually; Fig. 1A) have impaired water quality, reducing both water-column transparency and hypolimnetic dissolved oxygen levels (Laws 1981, Herdendorf 1983, Rosa and Burns 1987, Bertram 1993). Bottom anoxia, in turn, eliminated important benthic macroinvertebrate prey species (e.g., burrowing mayflies, Hexagenia limbata and $H$. rigida) by the mid-1950s (Britt 1955, Carr and Hiltunen 1965), as well as reduced the thermal habitat for cold-water fishes of the central basin. These productivity-induced losses of prey and habitat were implicated, at least in part, in the decline of several highly valued commercial and sport fishes (e.g., lake whitefish Coregonus clupeaformis, burbot Lota lota) in Lake Erie by the 1960s (Hartman 1972, Leach and Nepszy 1976, Laws 1981). In turn, Lake Erie commonly was referred to as the "Dead Sea of North America" during the 1960s and 1970s (Sweeney 1993). Similar accounts of the impact of eutrophication on other freshwater systems abound (e.g., Edmondson 1969, Colby et al. 1972, Hartman 1972, Hartmann and Nümann 1977, Laws 1981).

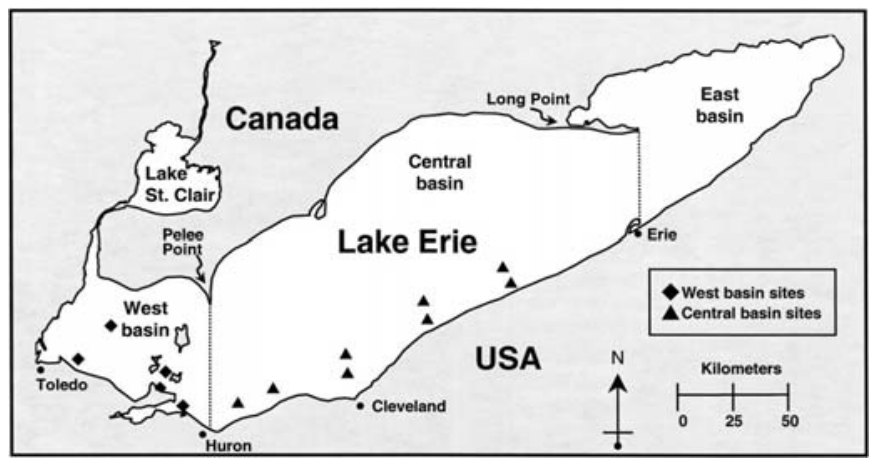

Fig. 2. Historical Ohio Department of Natural Resources-Division of Wildlife bottom-trawling sites in the west $(n=$ 5) and central $(n=8)$ basins of Lake Erie. Fish were collected during late September-early October, 1969-1996 at each site $(n=1-2$ replicates/site). See Methods: Data collection for additional details. 


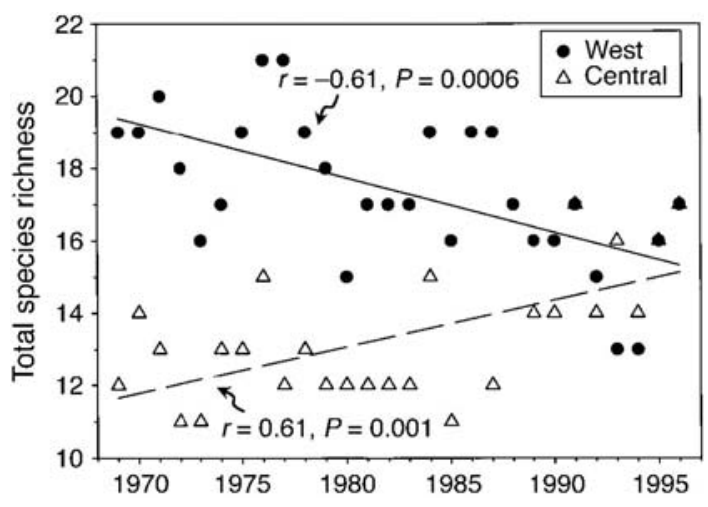

Fig. 3. Total species richness in Lake Erie's west ( $n=5$ sites) and central $(n=8$ sites) basins during late Septemberearly October, 1969-1996. Correlation coefficients $(r)$, probability values $(P)$, and regression lines also were included.

\section{Oligotrophication in Lake Erie}

To rehabilitate the waters of Lake Erie, phosphorus abatement programs were initiated as part of the Great Lakes Water Quality Agreement of 1972 (Dolan 1993). The Lake Erie ecosystem quickly responded to these abatement efforts. Overall, reduced external loading of phosphorus led to reduced total phosphorus concentrations in the water column (Neilson et al. 1995; Fig. 1B), reduced phytoplankton biomass (Makarewicz and Bertram 1991, Makarewicz $1993 b$ ), and improved water quality in both western and central Lake Erie. Owing to physical and biological differences between basins (see Methods: Study site), however, water quality improvements differed between them. Although bottom anoxia declined in both basins (Makarewicz and Bertram 1991, Bertram 1993, Charlton et al. 1993, Neilson et al. 1995), the shallow, productive west basin also experienced improved water clarity, whereas the central basin did not (Fig. 1C). As in other systems, reduced bottom anoxia allowed once-important benthic macroinvertebrate prey to recover in both lake basins (Krieger and Ross 1993, Krieger et al. 1996). Although phosphorus abatement programs were primarily responsible for reduced primary and secondary productivity through the mid-1980s (Makarewicz and Bertram 1991, Makarewicz 1993a, b), invasion of the zebra mussel Dreissena polymorpha conceivably magnified these reductions in recent years (Holland 1993, Nicholls and Hopkins 1993).

\section{Methods}

Study site

Although Lake Erie is the shallowest of the Laurentian Great Lakes (average depth $=19$ $\mathrm{m})$, its large water volume $\left(484 \mathrm{~km}^{3}\right)$ makes it the 11 th largest freshwater lake in the world. Historically, Lake Erie has been highly productive across all trophic levels, which likely is a function of its warm temperature ( $>200$ frost-free days), mostly agricultural watershed (67\% of total basin land, other Great Lakes range 3-44\%), and short water retention time ( $2.6 \mathrm{yr}$ ) (Fuller et al. 1995). Among the Great Lakes, Lake Erie is unique, in that it has three geomorphologically distinct lake basins (Fig. 2). Below, we briefly describe the west and central basins (also see Herdendorf 1983, Fuller et al. 1995), which are the focus of our analyses.

Waters west of an imaginary line extending from Pelee Point, Ontario to Huron, Ohio comprise Lake Erie's west basin (Fig. 2). Waters east of this line, but west of another line drawn between Long Point, Ontario and Erie, Pennsylvania, comprise the central basin (Fig. 2). The west basin has less volume $\left(25 \mathrm{~km}^{3}\right)$, is shallower (mean depth $\left.=7.4 \mathrm{~m}\right)$, and has a shorter water 
retention time $(51 \mathrm{~d})$ than the central basin $\left(305 \mathrm{~km}^{3}, 18.5 \mathrm{~m}, 635 \mathrm{~d}\right.$, respectively). Biological production across all trophic levels is typically greater in the west than central basin for three reasons: (1) depth and water volume increase from west to east, (2) temperature is higher in the west relative to the east, and (3) $>90 \%$ of the water entering Lake Erie does so from west basin tributaries (i.e., Detroit, Maumee, and Sandusky Rivers).

\section{Data collection}

As part of routine assessment surveys, ODNR-ODW conducted bottom trawl collections (semi-balloon trawl: 10.7-m headrope, 6.4-mm cod-end mesh; $n=1-2$ replicates/site; boat speed $=0.8 \mathrm{~m} / \mathrm{s}$; tow duration $=10-15 \mathrm{~min}$; standardized to catch-per-hour-of-trawling (CPHT) ) during daylight hours at fixed sites in western $(n=5$ sites $)$ and central $(n=8$ sites $)$ Lake Erie during late September to early October, 1969-1996 (Fig. 2). In both basins, sampling stations were stratified by depth (3-m depth contours), such that sampling occurred in both nearshore and offshore Ohio waters. Following collection, fish were identified to species, aged (using length-age keys), and counted. Although subsampling occasionally was used to estimate abundance of prey species (see Table 1), for species discussed herein (i.e., "signal"' species; see Methods: Signal species richness and abundance), all individuals were counted. For all analyses, catch data were $\log _{10}($ CPHT +1$)$-transformed because standard deviations were correlated with their means.

Several shortcomings exist with this data series. First, the duration of individual trawls never exceeded $10 \mathrm{~min}$ at nearshore stations and $15 \mathrm{~min}$ at offshore stations. Before 1990, however, duplicate trawls conducted at a site were not considered independent because their trawl swaths overlapped (trawls were conducted in opposite directions). As such, catches from duplicate trawls within a site were summed (producing trawl times of 20 or $30 \mathrm{~min}$ ). Because original data sheets no longer exist, we could not recalculate averages. Second, total annual effort spent trawling was reduced in both basins in recent years. Specifically, total trawling effort in the west basin declined from $\sim 120 \mathrm{~min}$ to $\sim 50 \mathrm{~min}$ beginning in 1992 , while it was reduced from $\sim 240$ min to $\sim 120$ min beginning in 1993 in central basin waters. And third, because of possible misidentification errors of young-of-year (i.e., age-0) silver chubs Macrhybopsis storeriana, sand shiners Notropis stramineus, ghost shiners $N$. buchanani, and mimic shiners $N$. volucellus in the field, we combined these species into a single taxonomic category (i.e., minnows) for all analyses.

\section{Total species richness}

As a first step in identifying changes in fish community structure that occurred during 1969-1996 in western and central Lake Erie, we quantified total species richness (i.e., the number of different species captured annually across all bottom trawls) for each basin. To be included in these or subsequent analyses, each species had to be captured in greater than three years of the 28-yr data set. We imposed this limit to reduce the influence of extremely rare species on species richness trends and ordination analyses (Jongman et al. 1995). In addition, recently (post-1969) established exotic white perch Morone americana and round goby Neogobius melanostomus were not included in any analyses; we did not want species richness trends influenced by recent exotic invaders. Annual species richness values were plotted against time (1969-1996) and analyzed using univariate linear regression $(\alpha=0.05)$. 
Table 1. Common and scientific names of fishes (Robins et al. 1991) captured in west and central Lake Erie, 19691996.

\begin{tabular}{|c|c|c|c|}
\hline \multirow[b]{2}{*}{ Common name } & \multirow[b]{2}{*}{ Scientific name } & \multicolumn{2}{|c|}{ Years } \\
\hline & & West & Central \\
\hline Alewife: & Alosa pseudoharengus & 26 & 22 \\
\hline Black crappie $\dagger$ & Pomoxis nigromaculatus & 7 & 0 \\
\hline Blackside darter & Percina maculata & 2 & 0 \\
\hline Bluegill & Lepomis macrochirus & 8 & 1 \\
\hline Bowfin & Amia calva & 2 & 0 \\
\hline Brown bullhead $\uparrow$ & Ameiurus nebulosus & 23 & 1 \\
\hline Burbot & Lota lota & 1 & 7 \\
\hline Channel catfish $\dagger$ & Ictalurus punctatus & 25 & 25 \\
\hline Common carp & Cyprinus carpio & 25 & 16 \\
\hline Emerald shiner: & Notropis atherinoides & 28 & 28 \\
\hline Freshwater drum & Aplodinotus grunniens & 28 & 28 \\
\hline Ghost shiner & Notropis buchanani & 21 & 9 \\
\hline Gizzard shad" & Dorosoma cepediamum & 28 & 28 \\
\hline Goldfish & Carassius auratus & 16 & 1 \\
\hline Greenside darter & Etheostoma blennioides & 1 & 0 \\
\hline Johnny darter $\dagger$ & Etheostoma nigrum & 5 & 1 \\
\hline Lake whitefish $\downarrow$ & Coregonus clupeaformis & 0 & 7 \\
\hline $\log$ perch $\dagger$ & Percina caprodes & 19 & 9 \\
\hline Longnose gar & Lepisosteus osseus & 1 & 0 \\
\hline Mimic shinert & Notropis volucellus & 21 & 9 \\
\hline Northern hog sucker & Hypentelium nigricans & 1 & 1 \\
\hline Pumpkinseed $\pitchfork$ & Lepomis gibbosus & 6 & 0 \\
\hline Quillback $\uparrow$ & Carpiodes cyprinus & 17 & 3 \\
\hline Rainbow smelt: & Osmerus mordax & 27 & 25 \\
\hline Rock basst & Ambloplites rupestris & 4 & 1 \\
\hline Round goby $\S$ & Neogobius melanostomus & 0 & 4 \\
\hline Sand shinert & Notropis stramineus & 21 & 9 \\
\hline Sauger & Stizostedion canadense & 2 & 0 \\
\hline Sea lamprey & Petromyzon marinus & 1 & 0 \\
\hline Shorthead redhorse & Moxostoma macrolepidotum & 0 & 1 \\
\hline Silver chubtq & Macrhybopsis storeriana & 21 & 9 \\
\hline Smallmouth bass ${ }^{*}$ & Micropterus dolomieu & 11 & 4 \\
\hline Spottail shinert: & Notropis hudsonius & 28 & 26 \\
\hline Stonecat & Noturus flavus & 3 & 6 \\
\hline Trout-perch: & Percopsis omiscomaycus & 28 & 28 \\
\hline Walleye\| & Stizostedion vitreum & 28 & 25 \\
\hline White bass: & Morone chrysops & 28 & 28 \\
\hline White crappiet & Pomoxis annularis & 18 & 12 \\
\hline White perch: & Morone americana & 19 & 19 \\
\hline White sucker ${ }^{t}$ & Catostomus commersoni & 4 & 10 \\
\hline Yellow perch" & Perca flavescens & 28 & 28 \\
\hline
\end{tabular}

Note: "Years" reflects years of presence out of 28 yr in each basin.

$\uparrow$ Species included in signal species analyses. Each of these species was present in at least one lake basin for more than three years of the 28-yr trawl series.

$\$$ Species excluded from signal species analyses because they are common prey of walleye, the lake's top predator (Knight et al. 1984, Francis 1992, Hartman and Margraf 1992, Knight and Vondracek 1993).

$\S$ Round goby was removed from analyses because it is a recent $(\sim 1993)$ exotic invader

|| Walleye was removed from signal species analyses because regulated fishing mortality via interagency management (Hatch et al. 1987) confounds our ability to assess the role of lake productivity in influencing its abundance.

I Owing to possible misidentification errors of young-of-year (i.e., age-0) silver chubs, sand shiners, ghost shiners, and mimic shiners in the field, these species were placed into a single taxonomic category (i.e., minnows) for all analyses.

\section{Signal species richness and abundance}

To further assess fish community change, we quantified species richness and abundance trends for a subset of the Lake Erie fish assemblage, which we termed signal species (see Table 1). A few general characteristics define signal species. First, each was captured in greater than three years of the 28-yr trawl series, such that extremely rare species would not influence our results. Second, none of the signal species serves as prey for walleye Stizostedion vitreum, the lake's top predator (Knight et al. 1984, Francis 1992, Hartman and Margraf 1992, Knight and Vondracek 1993, Kershner and Stein 1998). We excluded the 10 most common walleye prey species (Table 1) from our signal species analyses to eliminate predation as a confounding factor of fish community change, given that predator-driven shifts in prey abundance occurred in Lake Erie during 1969-1996 (Makarewicz and Bertram 1991, Ludsin et al. 1998; S. Ludsin, unpublished data). Third, no signal species occurred every year of the $28 \mathrm{yr}$ data set. Species captured during all $28 \mathrm{yr}$ were removed because they did not influence species richness trends. 
Although signal species always comprised a small portion of the total catch in both basins (see Results), we used their abundance patterns to better understand how fish communities within Lake Erie responded to phosphorus-driven improvements in water quality. This approach is similar to that of Kremen (1992), who used rare-species abundances, in combination with ordination analyses and life-history characteristics, to assess how butterfly community structure changed along topographic, moisture, and disturbance gradients. To use rare signal species as indicators of habitat quality, we surveyed the literature and grouped species into tolerance (i.e., ability to tolerate conditions of eutrophy, such as low oxygen and turbidity) and thermal guilds, as well as identified species with detritivorous feeding habits.

Signal species vary in their ability to tolerate anoxia or turbidity (Table 2). As such, we explored shifts in signal species richness using univariate linear regression. Shifts in abundance of the entire signal species assemblage were also quantified in both basins using detrended correspondence analysis (DCA; Hill 1979, as modified by McCune and Mefford 1995). Conceptually similar to principal components analysis (PCA), DCA is an eigenanalysis technique that arranges points (in this case years) along theoretical, orthogonal axes with the intent of maximizing their dispersion (Jongman et al. 1995, McCune and Mefford 1995). These axes are assumed to represent underlying environmental gradients that, ideally, are correlated with known environmental variables (in our case, lake productivity). Because DCA assumes species have unimodal response curves with respect to the underlying gradients, its use is only appropriate where gradients exceed 2.0 standard deviations (SD) in length (Jongman et al. 1995). Both signal species analyses (one for each lake basin) met this requirement. We used the downweighing option for DCA because relatively rare species can unduly influence ordination results (Jongman et al. 1995, McCune and Mefford 1995).

We tested for differences among clusters of points on DCA ordination diagrams, grouped into decades (i.e., 1970s vs. 1990s), with the nonparametric, multiresponse permutation procedure (MRPP) (Berry et al. 1983, as modified by McCune and Medford 1995). Though similar to discriminant analysis, this procedure does not have strict requirements of multivariate normality and homogenous variances (McCune and Medford 1995). We also correlated DCA axis scores with species abundance and productivity data to understand what factors might be driving ordination patterns (Hinch et al. 1991, Jongman et al. 1995, McCune and Mefford 1995). Because each axis was correlated with multiple biological variables, we used a Bonferroni adjustment of the significance level of each individual test $(\alpha=0.05 / n$, where $n$ was the number of correlations performed) to maintain an overall significance level of $\alpha=0.05$.

\section{Causes of species richness change}

To understand how (1) changes in nutrient loading, (2) recent exotic invaders (e.g., zebra mussels, white perch, and round gobies), and (3) reductions in sampling intensity might have influenced fish community structure, we relied on univariate linear regression. To assess the importance of changes in nutrient loading, we correlated annual lakewide phosphorus loading values (Fig. 1A) and basin-specific, total water-column phosphorus concentrations (Fig. 1B) with annual measures of species richness (both total and signal) values. To determine whether exotic invaders and changes in sampling intensity likely influenced species richness trends, we examined correlations between species richness (and in some cases, species abundance) and time (in years) both before and after an invasion occurred, and when sampling intensity was altered. Other potential causal mechanisms of change (e.g., wetland destruction, predation) are explored in the Discussion. 
Table 2. List of signal species in Lake Erie's west (W) and central (C) basins, 1969-1996, and their tolerance categories and feeding and thermal preferences.

\begin{tabular}{|c|c|c|c|c|c|c|c|c|c|}
\hline \multirow[b]{2}{*}{ Species } & \multirow[b]{2}{*}{ Basin } & \multirow{2}{*}{$\begin{array}{l}\text { Toler- } \\
\text { ance } \\
\text { guild } \dagger\end{array}$} & \multirow{2}{*}{$\begin{array}{l}\text { Thermal } \\
\text { guild } *\end{array}$} & \multirow{2}{*}{$\begin{array}{l}\text { Detritus } \\
\text { feeder } \S\end{array}$} & \multicolumn{2}{|c|}{ DCA axis $1 \|$} & \multicolumn{2}{|c|}{ Time } & \multirow[b]{2}{*}{ Trend\# } \\
\hline & & & & & $r$ & $P$ & $r$ & $P$ & \\
\hline Black crappie & W & $\mathrm{T}$ & cool & no & -0.34 & 0.08 & -0.28 & 0.15 & none \\
\hline Bluegill & W & $\mathrm{T}$ & warm & no & 0.20 & 0.31 & 0.20 & 0.30 & none \\
\hline Brown bullhead & W & $\mathrm{T}$ & warm & yes & -0.73 & 0.0001 & -0.73 & 0.0001 & - \\
\hline Burbot & C & I & cold & no & -0.56 & 0.002 & 0.49 & 0.008 & + \\
\hline \multirow[t]{2}{*}{ Channel catfish } & W & $\mathrm{T}$ & cool & no & -0.58 & 0.001 & -0.68 & 0.0001 & - \\
\hline & C & & & & 0.18 & 0.36 & 0.12 & 0.53 & none \\
\hline \multirow[t]{2}{*}{ Common carp } & W & $\mathrm{T}$ & warm & yes & -0.87 & 0.0001 & -0.92 & 0.0001 & - \\
\hline & C & & & & 0.46 & 0.015 & 0.12 & 0.53 & none \\
\hline Goldfish & W & $\mathrm{T}$ & warm & yes & -0.76 & 0.0001 & -0.80 & 0.0001 & - \\
\hline Johnny darter & W & $\mathrm{M}$ & cool & no & -0.17 & 0.38 & -0.20 & 0.30 & none \\
\hline Lake whitefish & C & I & cold & no & -0.74 & 0.0001 & 0.69 & 0.0001 & + \\
\hline \multirow[t]{2}{*}{ Logperch } & W & $\mathrm{M}$ & cool & no & 0.23 & 0.23 & 0.03 & 0.87 & none \\
\hline & C & & & & 0.13 & 0.52 & 0.04 & 0.85 & none \\
\hline Pumpkinseed & W & $\mathrm{T}$ & warm & no & -0.36 & 0.06 & -0.33 & 0.09 & none \\
\hline Quillback & W & $\mathrm{T}$ & warm & yes & -0.45 & 0.02 & -0.49 & 0.009 & - \\
\hline Rock bass & W & I & cool & no & 0.55 & 0.002 & 0.51 & 0.006 & + \\
\hline \multirow[t]{2}{*}{ Minnows } & W & I & cool & no & 0.82 & 0.0001 & 0.77 & 0.0001 & + \\
\hline & C & & & & -0.55 & 0.003 & 0.52 & 0.005 & + \\
\hline \multirow{2}{*}{ Smallmouth bass } & W & I & warm & no & 0.56 & 0.002 & 0.42 & 0.03 & + \\
\hline & $\mathrm{C}$ & & & & -0.54 & 0.003 & 0.54 & 0.003 & + \\
\hline Stonecat & C & I & cool & no & -0.07 & 0.71 & 0.33 & 0.09 & none \\
\hline \multirow[t]{2}{*}{ White crappie } & W & $\mathrm{T}$ & cool & no & -0.67 & 0.0001 & -0.79 & 0.0001 & - \\
\hline & C & & & & 0.63 & 0.0003 & -0.53 & 0.004 & - \\
\hline \multirow[t]{2}{*}{ White sucker } & W & $\mathrm{T}$ & cool & no & -0.21 & 0.28 & -0.31 & 0.11 & none \\
\hline & C & & & & -0.59 & 0.0009 & 0.59 & 0.001 & + \\
\hline
\end{tabular}

Note: Owing to potential misidentification of silver chubs, sand shiners, ghost shiners, and mimic shiners in the field, these species were combined into a single taxonomic category (i.e. minnows)

$+\mathrm{T}=$ tolerant of eutrophy (i.e., low bottom oxygen or high turbidity); $\mathrm{I}=$ intolerant of eutrophy; $\mathrm{M}=$ moderately tolerant of eutrophy. Tolerance categories were determined by literature survey (Angermeier and Karr 1986, Leonard and Orth 1986, Minns et al. 1994, Lyons et al. 1996, Paller et al. 1996, Whittier and Hughes 1998).

\$ Thermal guilds follow Magnuson and Lathrop (1992) according to whether the midpoint of preferred temperature falls in the following ranges: cold $=10.0-17.0^{\circ} \mathrm{C} ; \mathrm{cool}=18.0-26.0^{\circ} \mathrm{C}$; and warm $>27.0^{\circ} \mathrm{C}$. Thermal guilds were determined by literature survey (Trautman 1981, Becker 1983, Magnuson and Lathrop 1992).

$\S$ A "yes" indicates that these species are facultative detritivores (i.e., at least one study has demonstrated that detritus can comprise $>25 \%$ of diet biomass).

$\|$ Pearson correlation coefficient $(r)$ and probability value $(P)$ describing the correlation between DCA axis 1 (Fig. 5) and each species abundance $\left(\log _{10}(\mathrm{CPHT}+1)\right.$-transformed $)$. Note that, a negative $r$ value in the west basin indicates that the species declines through time, whereas a negative $r$ value in the central basin signifies that the species increased through time.

ๆ Pearson correlation coefficient $(r)$ and probability value $(P)$ describing the correlation between time (1969-1996) and each species abundance $\left(\log _{10}(\right.$ CPHT +1$)$-transformed). A positive $r$ value signifies that the species increased through time.

\# Trends through time were based upon correlations between species abundance data and DCA axis 1 and time: $+=$ increase, $-=$ decrease; and none $=$ no linear trend.

\section{Results}

Forty-one species were captured in ODNR-ODW bottom trawls during 1969-1996 (Table 1). Of these species, 30 were captured in both basins, while eight were unique to the west basin and three to the central basin. Beyond being captured during most (if not all) years of the data set (Table 1), the 10 primary prey species dominated annual catches numerically, comprising 76.3-99.2\% of the catch in the west basin and 80.5-99.8\% in the central basin. Most other species (namely the signal species) were only present for a portion of the years (Table 1), and never represented $>10 \%$ of the catch in either basin during any given year.

\section{Total species richness}

Although the total number of species captured annually across western and central Lake Erie demonstrated no linear change since 1969 (both $r=-0.13$, both $P \geq 0.50$ ), when examined individually, each basin's fish community was dynamic. In the west basin, total species richness declined through time, whereas total species richness increased in the central basin (Fig. 3). 
Signal species richness and abundance

Of the 18 signal species examined, 10 were considered tolerant of eutrophy, six were considered intolerant, and two demonstrated moderate sensitivity (Table 2). Overall, dramatic shifts in signal species richness occurred during 1969-1996. In both basins, intolerant species richness increased (Fig. 4A, B). Simultaneously, the number of tolerant species captured declined in the west basin, but remained unchanged in the central basin (Fig. 4A, B, respectively). Note, however, that the number of tolerant species in the central basin during the 1970s was fewer than in the west basin during this time, and the number of tolerant species in both basins has converged in recent years.

DCA and MRPP showed that signal species abundance in the 1990s differed from the 1970s (including 1969) within both western (Fig. 5A) and central (Fig. 5B) Lake Erie (see Table 3 ). DCA axis 1 scores for the west basin were negatively correlated ( $P$ values were $<\alpha=0.05$ / $15=0.003$ ) with the abundances of several tolerant species (i.e., brown bullhead Ameiurus nebulosus, common carp Cyprinus carpio, channel catfish Ictalurus punctatus, goldfish Carassius auratus, and white crappie Pomoxis annularis). These results imply that these tolerant species were more common in the 1970s than in the 1990s (Table 2; Figs. 5A and 6). In contrast, several intolerant species (i.e., rock bass Ambloplites rupestris, smallmouth bass Micropterus dolomieu, and minnows) were positively correlated to DCA axis 1 in the west basin, signifying their recovery through time (Table 2; Figs. 5A and 7). In the central basin, white crappie was the only species positively correlated (i.e., $P$ values $<\alpha=0.05 / 10=0.005$ ) with DCA axis 1 (i.e., it declined through time; note the reversed direction of DCA axis 1 in Fig. 5B relative to Fig. 5A). Several intolerant species (i.e., burbot, lake whitefish, smallmouth bass, and minnows) and one tolerant species (i.e., white sucker Catostomus commersoni) were negatively related to DCA axis 1, again indicating their recovery in recent years (Table 2, Figs. 5B and 7).

\section{Causes of species richness change: oligotrophication}

Correlative evidence suggests that phosphorus regulation influenced fish community structure. System productivity (i.e., annual phosphorus loading data; see Fig. 1A) and total species richness were related within each basin. In western Lake Erie, total species richness (Fig. $8 \mathrm{~A})$, as well as tolerant species richness $\left(r^{2}=0.40, P=0.0004\right)$, declined with reduced phosphorus loading (i.e., these variables were positively related). In contrast, intolerant species richness was negatively related to phosphorus loading in the west basin $\left(r^{2}=0.18, P=0.02\right)$. In the central basin, total species richness increased with reduced phosphorus loading (Fig. 8B). This increase reflects a negative relationship between intolerant species and phosphorus loading $\left(r^{2}=0.30, P=0.004\right)$, and no relationship between tolerant species richness and productivity $\left(r^{2}\right.$ $=0.08, P=0.16)$. We also found that DCA axis 1 scores for both western $(r=0.67, P<0.001)$ and central $(r=-0.79, P<0.001)$ Lake Erie were strongly correlated with annual phosphorus loading. Finally, total species richness was related to total water-column phosphorus (our surrogate for lake productivity; see Fig. 1B) across both basins (Fig. 9).

\section{Causes of species richness change: exotics}

Before white perch reached high abundance in 1984, several tolerant species (i.e., common carp, goldfish, and white crappie in both basins) began to decline in abundance; all correlations of abundances of these species with time for 1969-1983 were less than -0.75 (all $P$ values $<0.001$; see Fig. 6 for unlogged abundance trends). Similarly, most tolerant species began to decline (Fig. 6) before the later establishment of zebra mussels $(\sim 1989)$ and round gobies 
( 1993). As for intolerant species, only the minnow assemblage increased in abundance before zebra mussels colonized the west basin in 1989 ( $r=0.72, P=0.0004$; Fig. 7).

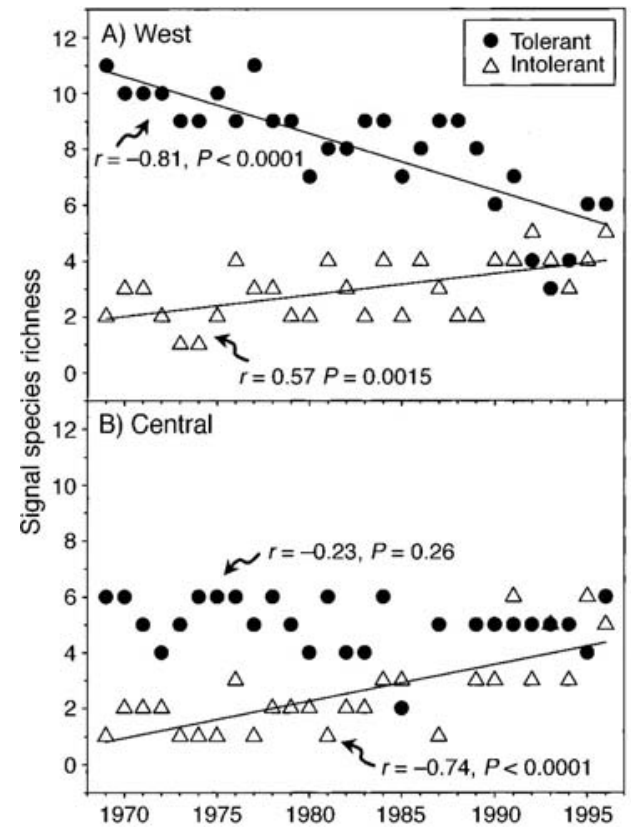

Fig. 4. Total number of fish species tolerant and intolerant of eutrophy (i.e., anoxia or turbidity) captured in Lake Erie's (A) west and (B) central basins, 1969-1996. Correlation coefficients $(r)$ and probability values $(P)$ were included for all trends, whereas regression lines were included only for significant trends $(\alpha=0.05)$.

\section{Causes of species richness change: sampling intensity}

Three lines of evidence suggest that reduced sampling intensity did not influence species richness trends. First, total species richness declined during 1969-1991 $(r=-0.42, P<0.05)$, a period of relatively constant sampling intensity. Second, standardized species abundance (i.e., CPHT) for most tolerant species declined before sampling effort decreased (see Fig. 6). Finally, (1) central basin species richness (see Fig. 3), (2) intolerant species richness in both basins (see Fig. 4A, B), (3) the abundance of most intolerant species (Table 2; Fig. 7), and (4) the abundance of tolerant white suckers (Table 2) increased in the face of reduced sampling effort.

Table 3. Detrended correspondence analysis (DCA) and multiresponse permutation procedure (MRPP) results from our signal species analyses of bottom trawl data collected during late September-early October, 1969-1996, in Lake Erie's west and central basins.

\begin{tabular}{|c|c|c|c|c|c|c|}
\hline \multirow[b]{2}{*}{ Basin } & \multirow[b]{2}{*}{$\begin{array}{c}\text { DCA } \\
\text { axis }\end{array}$} & \multirow{2}{*}{$\begin{array}{l}\text { Gradient } \\
\text { length } \\
\text { (SD) }\end{array}$} & \multirow[b]{2}{*}{$\lambda$} & \multirow[b]{2}{*}{$r^{2}$} & \multicolumn{2}{|c|}{ MRPP results } \\
\hline & & & & & $R_{\dagger}^{\dagger}$ & $P$ \\
\hline \multirow[t]{2}{*}{ West } & 1 & 2.35 & 0.393 & 0.521 & 0.357 & 0.000014 \\
\hline & 2 & 1.109 & 0.055 & -0.015 & & \\
\hline \multirow[t]{2}{*}{ Central } & 1 & 3.177 & 0.599 & 0.314 & 0.141 & 0.000028 \\
\hline & 2 & 2.111 & 0.174 & -0.062 & & \\
\hline
\end{tabular}

Notes: Only those species captured in bottom trawls greater than three years of the 28 -yr trawl series were included (see Table 1). Eigenvalues $(\lambda)$, gradient lengths (SD), and coefficients of determination ( $r^{2}$; see McCune and Mefford 1995) for year plots (see Fig. 5) are provided for the first two axes. For each basin, MRPP was conducted to determine whether abundance and species composition in each basin during the 1970s (including 1969) differed from the $1990 \mathrm{~s}(\alpha=0.05)$.

$\uparrow$ Positive values indicate that species abundance patterns between decades differed (McCune and Mefford 1995). 


\section{Discussion}

The species richness-productivity relationship

For both western and central Lake Erie, we suggest that nutrient regulation greatly influenced fish community organization. Specifically, phosphorus-driven reductions in tolerant species abundance caused species richness to decline in the west basin. In contrast, phosphorus abatement conceivably caused species richness to increase in the central basin by allowing a variety of species intolerant of degraded water quality to recover.

Three major changes in habitat quality occurred in the west basin during 1969-1996, a period of oligotrophication. First, bottom anoxia, which plagued this basin during hot, calm summers during the 1950s-1970s, disappeared, owing to reduced biogenic sedimentation and reduced bacterial respiration in bottom waters. Second, macroinvertebrate prey (e.g., Hexagenia spp.) recovered in soft sediments of the west basin as bottom anoxia declined. Finally, west basin water clarity improved, owing to reduced phytoplankton biomass. As we explain below, each of these changes likely influenced fish community dynamics in this basin.

In both lentic and lotic systems, oxygen levels in bottom sediments can regulate fish community composition (Ketchum 1969, Tonn and Magnuson 1982, Nürnberg 1995); fish species richness tends to be higher with oxygen saturation relative to oxygen deprivation (Tonn and Magnuson 1982, Nürnberg 1995). Hence, we believe that reduced anoxia both directly (for each species has a documented tolerance) and indirectly (via recovery of macroinvertebrate communities) allowed intolerant fishes to recover in the west basin. Although we do not have historical diet data for intolerant fishes, recent (1995-1998) diet information from the west basin reveals that the proportion of Hexagenia spp. in silver chub diets has mirrored the recovery of these prey in bottom sediments (K. Krieger, unpublished data). Similarly, other benthic Lake Erie fishes (e.g., trout-perch Percopsis omiscomaycus, yellow perch Perca flavescens, walleye) have increased their consumption of Hexagenia during the past decade, approaching historical levels (Lake Erie Forage Task Group 1999; K. Krieger, unpublished data). Because Hexagenia spp. historically were important prey for a variety of Lake Erie fishes (Boesel 1937, Becker 1983) and diet selection can strongly influence growth and survival of fishes (e.g., Ludsin and DeVries 1997, Kershner and Stein 1998), continued recovery of macroinvertebrate prey, including non-Hexagenia species (Botts et al. 1996, Ricciardi et al. 1997), should lead to continued success of intolerant fishes. Enhanced light penetration also ought to aid fish species recovery in this basin by increasing prey detection capabilities (O'Brien 1987, Bergman 1991, Persson et al. 1991, Miner and Stein 1993), as well as by providing added foraging habitat and refuge from predation (sensu Savino and Stein 1982, Gregory and Levings 1996) via enhanced macrophyte cover (Stuckey and Moore 1995).

Although proximal mechanisms that allowed for intolerant species recovery may be clear, we are less certain about what caused tolerant species in the west basin to decline. Because many of these tolerant species are facultative detritivores (see Table 2), their decline may be linked to reduced detrital mass (availability) or its nutritional value following reduced planktonic production; in the west basin, phytoplankton biomass has declined by $\sim 65 \%$ (Makarewicz and Bertram 1991, Makarewicz 1993b), whereas crustacean zooplankton biomass has declined by as much as 60\% (Makarewicz and Bertram 1991, Makarewicz 1993a, Weisgerber 2000). Given that reduced species detrital mass has been linked to reduced species diversity (e.g., species richness) in other systems (Gascon and Leggett 1977, Nakashima et al. 1977, Henderson and Crampton 1997), further exploration of this mechanism is warranted. 

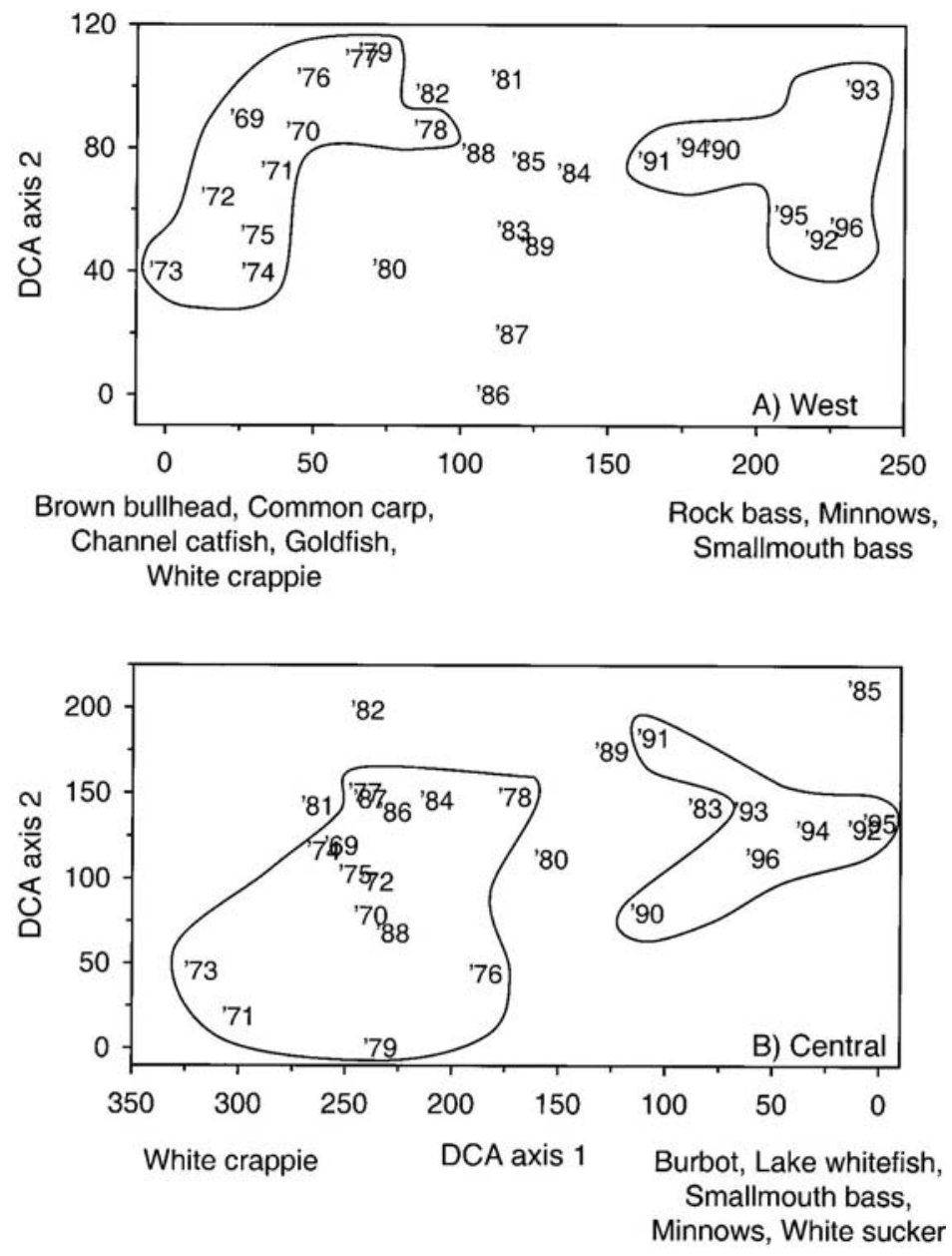

Fig. 5. Detrended correspondence analysis (DCA) ordination diagrams of signal species abundances $\left(\log _{10}(\mathrm{CPHT}+\right.$ 1)-transformed) during late September-early October, 1969-1996, in Ohio waters of the (A) west ( $n=5$ sites) and (B) central $(n=8$ sites) basins of Lake Erie. Only those species captured in a basin in more than three years of the 28 -yr bottom trawl series (see Table 1) were included in these analyses. Using the multiresponse permutation procedure (MRPP), we found that fish community structure differed $(\alpha=0.05)$ between the 1970s and the 1990s (i.e., the sets of circled clusters). Species names on the left of DCA axis 1 represent those species more abundant during the 1970s than during the 1990s, while those on the right of DCA axis 1 were more common in recent years (see Table 2). See Table 3 for axis lengths (100 units =1 SD) and eigenvalues, as well as MRPP results.

Alternatively, tolerant species may have declined owing to inferior competitive abilities, relative to intolerant fishes, under conditions of improved water clarity (sensu Bergman and Greenberg 1994, Leibold et al. 1997, Rodriguez and Lewis 1997). For example, fish species composition in Swedish lakes is linked to the differential abilities of fish to compete for prey under different light regimes. In productive lakes with low light penetration, ruffe (Gymoncephalus cernuus) tend to dominate fish biomass, given their highly developed sensory organelles that enable them to continue to feed at low light (Bergman 1991, Persson et al. 1991). In contrast, European perch (Perca fluviatilis) have a competitive foraging advantage over ruffe in low productivity systems, and hence, tend to dominate there (Bergman 1991, Persson et al. 1991). Because nutrient abatement programs are common, determining exactly how reduced productivity leads to loss of tolerant species remains an important, interesting question. 

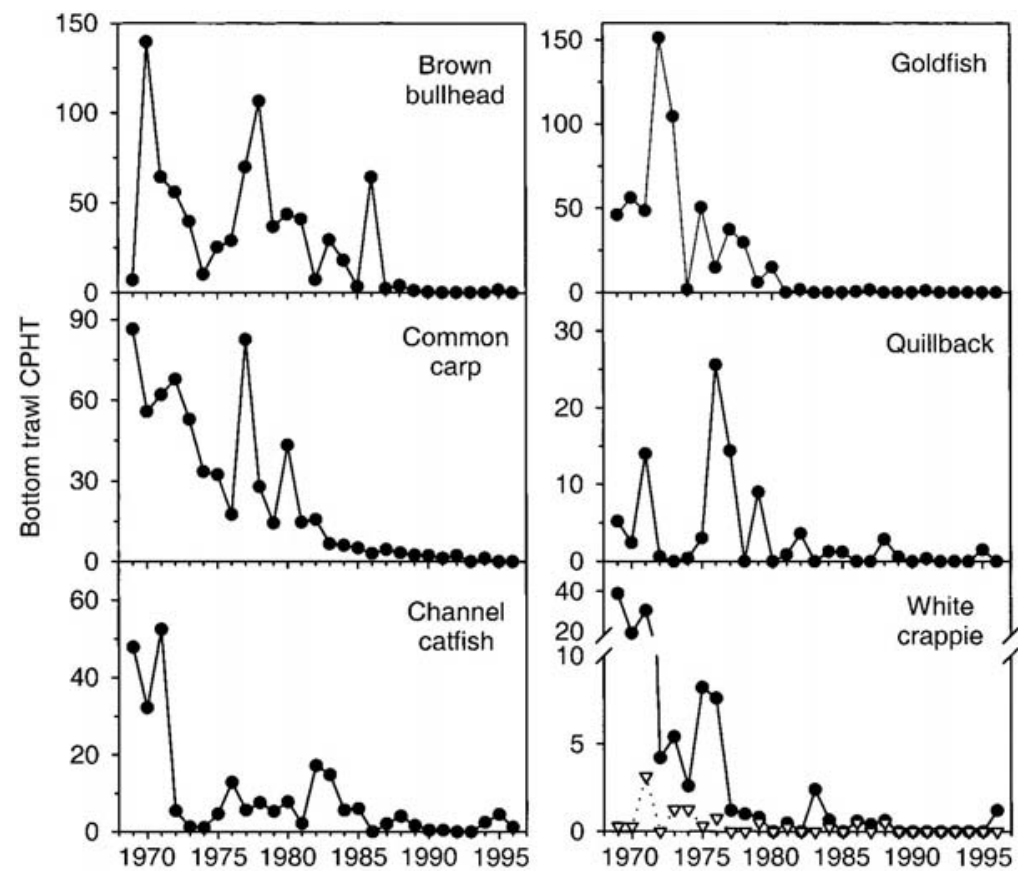

Fig. 6. Unlogged catch-per-hour-of-trawling (CPHT) estimates of species tolerant of eutrophy (i.e., anoxia or turbidity) that declined through time (see Table 2; Fig. 5) in Lake Erie's west ( $n=5$ sites, solid circles) and central ( $n=8$ sites, open triangles; white crappie only) basins. Error estimates were not included in order to reduce clutter. Note that vertical axes differ among panel.

Given that water clarity did not change, the reduction in bottom anoxia in the central basin since the 1970s (Makarewicz and Bertram 1991, Bertram 1993) seems the most plausible explanation for intolerant species recovery in this basin. Because most recovering intolerant species are cool- or cold-water stenotherms (see Table 2), enhanced oxygen levels in deep, cold bottom waters likely played a pivotal role in their recent success by enhancing preferred thermal habitat and benthic macroinvertebrate prey. Indeed, anthropogenic oxygenation of the hypolimnion of Amisk Lake, Alberta allowed cisco Coregonus artedi, a congener of lake whitefish, to once again inhabit cold hypolimnetic waters, as opposed to thermally sub-optimal (i.e., warm) epilimnetic waters (Aku et al. 1997). Ultimately, increased thermal habitat led to increases in cisco diet biomass, population size, and biomass (Aku and Tonn 1997, 1999). The fact that the decline of several cool- and cold-water species (e.g., lake whitefish, burbot) in Lake Erie during the 1950s was in part linked to enhanced bottom anoxia (Beeton 1965, Laws 1981) also suggests the importance of anoxia as a regulatory agent.

We found that traditional unimodal models, which suggest that a diversity peak emerges at intermediate levels of productivity, appear to fit our data. Using total water-column phosphorus as a surrogate for lake productivity because basin-specific phosphorus loading data were not available, we observed that data from the oligotrophic central basin generally fell on the ascending limb of the hump-shaped curve, whereas data from the mesotrophic to eutrophic west basin were positioned at the curve's maximum. Interestingly, even during the height of eutrophication in Lake Erie, phosphorus was only sufficiently high $\left(\sim 100 \mathrm{mg} / \mathrm{m}^{3}\right)$ in the west basin to be considered eutrophic (eutrophic range $=16-386 \mathrm{mg} / \mathrm{m}^{3}$; Wetzel 1983), while it never even approached the hypereutrophic range $\left(750-1200 \mathrm{mg} / \mathrm{m}^{3}\right.$; Wetzel 1983). As such, we can only speculate that species richness would eventually decline at higher levels of productivity 
with higher productivity would come turbid and acidic waters, likely low in oxygen (Wetzel 1983). Thus, we would expect that few species (i.e., only those most tolerant of anoxia and turbidity) would persist under hypereutrophic conditions, resulting in low species richness (sensu Tonn and Magnuson 1982, Nürnberg 1995). Given that most previous explorations of productivity and species richness were derived from samples collected at spatially distinct sites within nondegraded habitats, and few focused upon vertebrates, we were encouraged that these models appear sufficiently robust to explain fish community dynamics (i.e., species replacement/succession) of a recovering system.
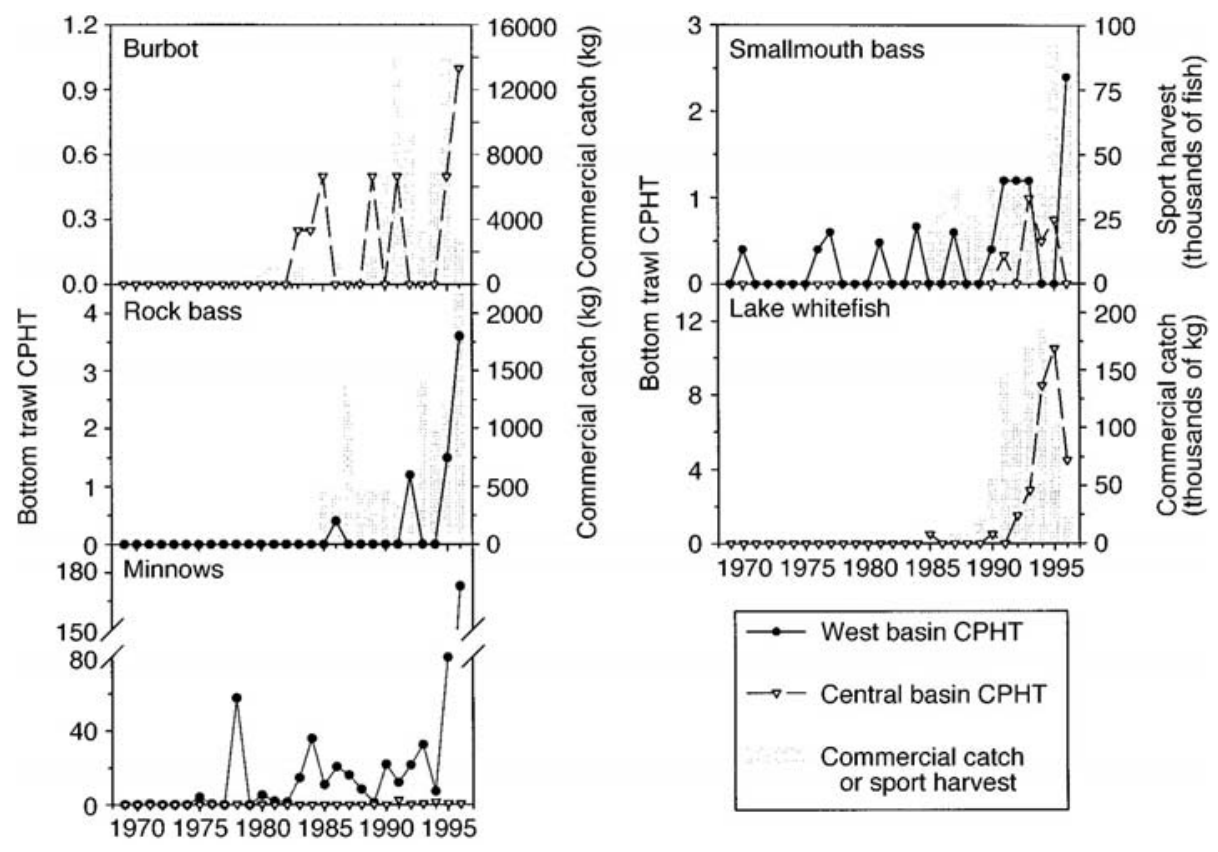

Fig. 7. Unlogged catch-per-hour-of-trawling (CPHT), commercial catch, and sport angler harvest of species intolerant of eutrophy (i.e., anoxia or turbidity) that increased through time (see Table 2; Fig. 5) in Lake Erie. Bottom trawl abundances (i.e., CPHTs) were determined from ODNR-ODW bottom trawling conducted in Lake Erie's west $(n=5$ sites) and central $(n=8$ sites) basins during late September-early October, 1969-1996. Commercial catch data (kilograms) for burbot, rock bass, and lake whitefish in U.S. waters during 1969-1996 were provided by the Great Lakes Fishery Commission (Ann Arbor, Michigan), while the lakewide sport angler harvest (thousands of fish) for smallmouth bass during 1985-1996 was obtained from Ohio Department of Natural Resources-Division of Wildlife (1997). Note that vertical axes differ among panels.

\section{Other potential causes of species richness change}

Other possible causes of change in Lake Erie's fish communities include changes in predation pressure, establishment of exotic species, and wetland modification (e.g., diking, draining). Secondarily, increased water clarity and reduced sampling effort (i.e., sampling biases) could have driven the changes we observed in species richness.

Although walleye, the top predator in western and central Lake Erie, reached record levels during the mid-1980s (Hatch et al. 1987), predation did not drive declines in tolerant species abundance; walleye simply did not feed on tolerant species in Lake Erie during 19691996 (Knight et al. 1984, Francis 1992, Hartman and Margraf 1992, Knight and Vondracek 1993, Kershner and Stein 1998). Even during 1995, a year of very low prey species abundance (Kershner and Stein 1998), no tolerant species occurred in $>1200$ walleye diets sampled throughout the year (M. Kershner, unpublished data). 
Considering recent exotic invaders, correlative evidence suggests that white perch, zebra mussels, and round gobies did not play a major role in the decline of tolerant species; again, most tolerant species began to decline in abundance prior to the establishment of these exotics. However, although the minnow assemblage began to increase in abundance prior to zebra mussel establishment, zebra mussels may have indirectly aided the recovery of intolerant species by enhancing water visibility (Holland 1993, Nicholls and Hopkins 1993) and benthic macroinvertebrate communities (Botts et al. 1996, Ricciardi et al. 1997).

Although we could not explicitly test the role of wetlands, the minor wetland losses that occurred since 1969 (Maynard and Wilcox 1996) also seem unimportant in driving the loss of tolerant species, given the recovery of rock bass, smallmouth bass, and white sucker, species common to Lake Erie wetlands (Johnson 1989, Jude and Pappas 1992). Certainly, however, these losses may have reduced the rate of recovery of intolerant species.

Previous work has demonstrated that sampling effort can bias diversity indices. This criticism is especially true for species richness, which typically increases with sampling effort (Magurran 1988). Because sampling effort was reduced by about twofold in both basins beginning in the early 1990s, reduced species richness in the west basin could have been an artifact of reduced sampling effort. Analysis of the timing of tolerant species declines, combined with the fact that the abundance of several species and central basin species richness increased in the face of declining sampling effort, suggests otherwise. Had the abundance of tolerant species remained constant through the early 1990s, only declining thereafter, then our data could be assumed to be biased. As such, we hypothesize that the loss of tolerant species in the west basin was caused by potentially poor recruitment (or survival), as mediated by reduced system productivity. For similar reasons (i.e., many species increased in abundance through time), we suggest that gear avoidance issues associated with improved water clarity did not bias our trawl catch. Analyses of the relationship between trawl catches and water clarity in Lake Erie support this contention (Kershner and Stein 1998; S. Ludsin, unpublished data).

\section{Management implications}

Although we knew a priori that nutrient regulation could improve water quality and rehabilitate lower trophic levels, we did not know how fish communities would respond to oligotrophication. First, much of our knowledge about the link between system productivity and fish community structure was derived from studies conducted during the 1970s, when systems were undergoing eutrophication (e.g., Colby et al. 1972, Hartman 1972, Leach and Nepszy 1976, Hartmann and Nümann 1977, Leach et al. 1977). Second, most previous investigations of oligotrophication primarily focused upon population responses (e.g., Hartmann and Quoss 1993, Ney 1996). Overall, most of these latter studies portrayed a dismal outlook for fisheries undergoing oligotrophication, citing how reduced nutrient loading would ultimately lead to reduced commercial and sport fish production (e.g., Ney 1996, Stockner et al. 2000). Even in Lake Erie, recent empirical evidence suggests that reduced phosphorus inputs have reduced economically important sport and commercial fishes, such as walleye (Gopalan et al. 1998, Kershner and Stein 1998, S. Ludsin, unpublished data). Clearly, our results counter this body of work, given that both sport and commercial species have recovered with oligotrophication. In Lake Erie, we found that tolerant species were replaced by intolerant ones in a sequence ordered in reverse of that observed during eutrophication. That this turnover of species occurred despite other anthropogenic perturbations (e.g., exotic species invasions, minor wetland losses), and occurred relatively rapidly, is encouraging. 


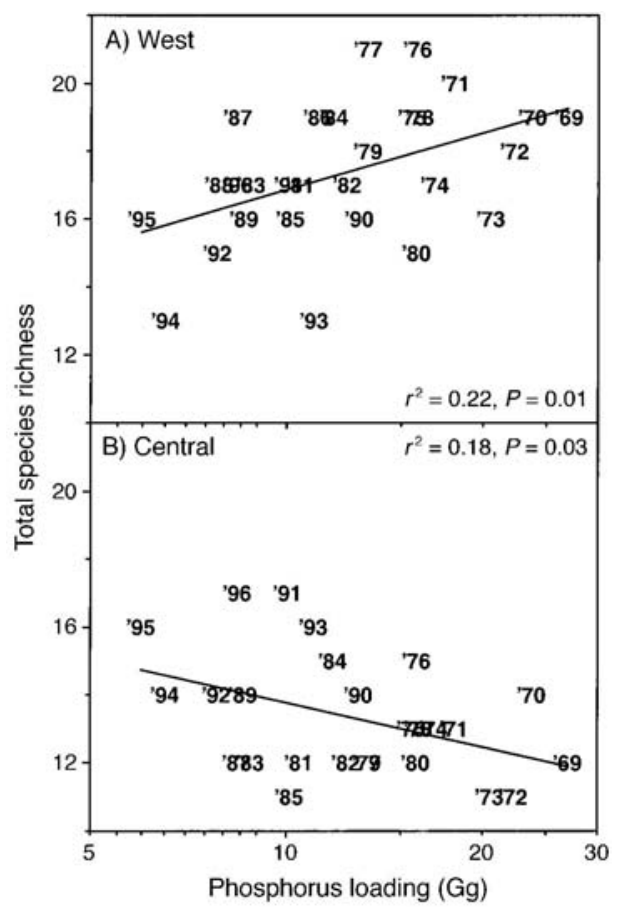

Fig. 8. Total fish species richness in Lake Erie's (A) west and (B) central basins vs. phosphorus loading estimates (note log scale; see Fig. 1A legend for data sources), 1969-1996. Coefficients of determination $\left(r^{2}\right)$ and probability values $(P)$ also were included.

Our findings also indicate that oligotrophication could lead to new and difficult management decisions. First, because changes in system productivity can drive fish species succession, tradeoffs in fishery resources are apt to occur with nutrient abatement. On Lake Erie, historically important sport (e.g., rock bass, smallmouth bass) and commercial (e.g., lake whitefish, burbot) fisheries have recently begun to increase, while major contemporary fisheries (e.g., walleye) have begun to decline. Thus, if fishery managers truly desire to guide expectations of their constituents (e.g., sport anglers, commercial seiners), such that their expectations match the capacity of the system to produce desired species, they will need to devote extra effort toward helping fishers understand, and hopefully accept, these impending trade-offs. Certainly, the next step of getting anglers to actually target different species (i.e., those that prosper in lowproductivity environments) could represent an even more daunting challenge. Second, because proper ecosystem management strategies attempt to conserve ecological structure and function, as well as sustain important human uses and ecosystem services (Meyer 1997, Brussard et al. 1998), managing for the health of ecosystems undergoing oligotrophication arguably will be tricky; nutrient abatement clearly has both associated benefits (e.g., improved water clarity, reduced bottom anoxia, recovery of macrophytes, Hexagenia spp., and sport and commercial fishes) and costs (e.g., reductions in the economically important walleye fishery). Basically, resource managers, ideally with public input, must decide whether to manage for continued ecosystem rehabilitation (continue on the path of oligotrophication) or perhaps for the success of only a few economically important species (relax controls on phosphorus loading). 


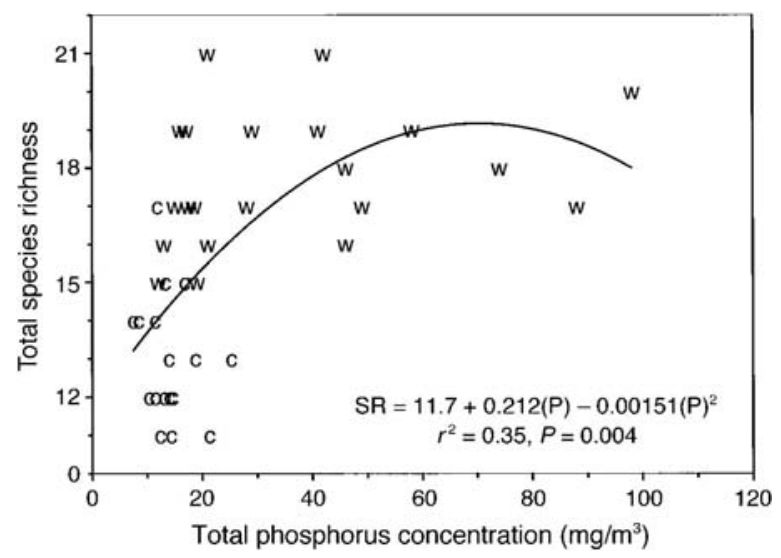

Fig. 9. Relationship between total fish species richness (SR; see Fig. 3 legend for source of data) and total watercolumn phosphorus concentrations. (P; see Fig. 1B legend for source of data) in west (w) and central (c) Lake Erie, 1969-1996. The nonlinear regression equations and relevant statistics ( $r^{2}$ and $P$ values) were included.

Despite these aforementioned dilemmas, we offer an optimistic outlook in an otherwise dismal state of affairs in fisheries management (e.g., overexploitation; Botsford et al. 1997). Simply put, nutrient abatement programs can lead to rapid, predictable fish community rehabilitation, not just improved water quality. Because both sport and commercial fishes have begun to recover with oligotrophication in Lake Erie, including waters outside of Ohio (Michigan Department of Natural Resources-Fisheries Division 1996, Lake Erie Coldwater Task Group 1998, Ontario Ministry of Natural Resources-Lake Erie Management Unit 1999), concern that reduced primary productivity will necessarily compromise all valued fishery resources seems unwarranted. In addition, we fully expect that recovering species will enjoy continued success as benthic macroinvertebrates and oxygen levels continue to recover in Lake Erie. Given that oligotrophication can lead to improved water quality and fisheries, without compromising system integrity, we encourage this approach to system rehabilitation.

\section{Acknowledgments}

We thank J. Deller, C. Knight, and J. Tyson for their help in compiling data, as well as J. Garvey, D. Jude, G. Kim, K. Rose, G. Steinhart, and one anonymous reviewer for their comments on previous drafts of this manuscript. Support for this work was provided by (1) Federal Aid in Sport Fish Restoration F-69-P (to R. A. Stein), administered jointly by the U.S. Fish and Wildlife Service and ODNR-ODW, (2) the Department of Evolution, Ecology, and Organismal Biology at The Ohio State University, and (3) a Presidential Fellowship awarded to S. A. Ludsin by The Ohio State University.

\section{Literature Cited}

Abramsky, Z., and M. L. Rosenzweig. 1984. Tilman's predicted productivity-diversity relationship shown by desert rodents. Nature 309:150-151.

Aku, P. M. K., L. G. Rudstam, and W. M. Tonn. 1997. Impact of hypolimnetic oxygenation on the vertical distribution of cisco (Coregonus artedi) in Amisk Lake, Alberta. Canadian Journal of Fisheries and Aquatic Sciences 54:2182-2195.

Aku, P. M. K., and W. M. Tonn. 1997. Changes in population structure, growth, and biomass of cisco (Coregonus artedi) during hypolimnetic oxygenation of a deep, eutrophic lake, Amisk Lake, Alberta. Canadian Journal of Fisheries and Aquatic Sciences 54:2196-2206.

Aku, P. M. K., and W. M. Tonn. 1999. Effects of hypolimnetic oxygenation on the food resources and feeding ecology of cisco in Amisk Lake, Alberta. Transactions of the American Fisheries Society 128:17-30. 
Angermeier, P. L., and J. R. Karr. 1986. Applying an Index of Biotic Integrity based on stream-fish communities: considerations in sampling and interpretation. North American Journal of Fisheries Management 6:418429.

Becker, G. C. 1983. Fishes of Wisconsin. University of Wisconsin Press, Madison, Wisconsin, USA.

Beeton, A. M. 1965. Eutrophication of the St. Lawrence Great Lakes. Limnology and Oceanography 10:240-254.

Bergman, E. 1991. Changes in abundance of two percids, Perca fluviatilis and Gymnocephalus cernuus, along a productivity gradient: relations to feeding strategies and competitive abilities. Canadian Journal of Fisheries and Aquatic Sciences 48:536-545.

Bergman, E., and L. A. Greenberg. 1994. Competition between a planktivore, a benthivore, and a species with ontogenetic diet shifts. Ecology 75:1233-1245.

Berry, K. J., K. L. Kvamme, and P. W. Mielke. 1983. Improvements in the permutation test for the spatial analysis of the distribution of artifacts into classes. American Antiquity 48:547-553.

Bertram, P. E. 1993. Total phosphorus and dissolved oxygen trends in the central basin of Lake Erie, 1970-1991. Journal of Great Lakes Research 19:224-236.

Boesel, M. W. 1937. The food of nine species of fish from the western end of Lake Erie. Transactions of the American Fisheries Society 67:215-233.

Botsford, L. W., J. C. Castilla, and C. H. Peterson. 1997. The management of fisheries and marine ecosystems. Science 277:509-515.

Botts, P. S., B. A. Patterson, and D. W. Schloesser. 1996. Zebra mussel effects on benthic invertebrates: physical or biotic? Journal of the North American Benthological Society 15:179-184.

Britt, N. W. 1955. Stratification in western Lake Erie in summer of 1953: effects on the Hexagenia (Ephemeroptera) population. Ecology 36:239-244.

Brussard, P. F., J. M. Reed, and C. R. Tracy. 1998. Ecosystem management: what is it really? Landscape and Urban Planning 40:9-20.

Carpenter, S. R., N. F. Caraco, D. L. Correll, R. W. Howarth, A. N. Sharpley, and V. H. Smith. 1998. Nonpoint pollution of surface waters with phosphorus and nitrogen. Ecological Applications 8:559-568.

Carr, J. F., and J. K. Hiltunen. 1965. Changes in the bottom fauna of western Lake Erie from 1930 to 1961. Limnology and Oceanography 10:551-569.

Charlton, M. N., J. E. Milne, W. G. Booth, and F. Chiocchio. 1993. Lake Erie offshore in 1990: restoration and resilience in the central basin. Journal of Great Lakes Research 19:291-309.

Colby, P. J., G. R. Spangler, D. A. Hurley, and A. M. McCombie. 1972. Effects of eutrophication on salmonid communities in oligotrophic lakes. Journal of the Fisheries Research Board of Canada 29:975-983.

Connell, J. H. 1961. The influence of interspecific competition and other factors on the distribution of the barnacle Chthamalus stellatus. Ecology 42:710-723.

Dolan, D. M. 1993. Point source loadings of phosphorus to Lake Erie: 1986-1990. Journal of Great Lakes Research 19:212-223.

Edmondson, W. T. 1969. Eutrophication in North America. Pages 124-149 in Eutrophication: causes, consequences, correctives. National Academy of Sciences, Washington, D.C., USA.

Edmondson, W. T. 1994. Sixty years of Lake Washington: a curriculum vitae. Lake and Reservoir Management 10:75-84.

Francis, J. T. 1992. Prey selectivity by walleye in western Lake Erie: an historical and inter-basin comparison. Thesis. Ohio State University, Columbus, Ohio, USA.

Fuller, K., H. Shear, and J. Wittig. 1995. The Great Lakes: an environmental atlas and resource book. Environment Canada and U.S. Environmental Protection Agency, Chicago, Illinois, USA.

Gascon, D., and W. C. Leggett. 1977. Distribution, abundance, and resource utilization of littoral zone fishes in response to a nutrient/production gradient in Lake Memphremagog. Journal of the Fisheries Research Board of Canada 34:1105-1117.

Gopalan, G., D. A. Culver, L. Wu, and B. K. Trauben. 1998. Effects of recent ecosystem changes on the recruitment of young-of-the-year fish in western Lake Erie. Canadian Journal of Fisheries and Aquatic Sciences 55:2572-2579.

Gregory, R. S., and C. D. Levings. 1996. The effects of turbidity and vegetation on the risk of juvenile salmonids, Onchorhynchus spp., to predation by adult cutthroat trout, O. clarkii. Environmental Biology of Fishes 47:279-288.

Guegan, J.-F., S. Lek, and T. Oberdorff. 1998. Energy availability and habitat heterogeneity predict global riverine fish diversity. Nature 391:382-384. 
Hartig, J. H., J. F. Kitchell, D. Scavia, and S. B. Brandt. 1991. Rehabilitation of Lake Ontario: the role of nutrient reduction and food web dynamics. Canadian Journal of Fisheries and Aquatic Sciences 48:1574-1580.

Hartman, W. L. 1972. Lake Erie: effects of exploitation, environmental changes and new species on the fishery resources. Journal of the Fisheries Research Board of Canada 29:899-912.

Hartman, K. J., and F. J. Margraf. 1992. Effects of prey and predator abundances on prey consumption and growth of walleyes in western Lake Erie. Transactions of the American Fisheries Society 121:245-260.

Hartmann, J., and W. Nümann. 1977. Percids of Lake Constance, a lake undergoing eutrophication. Journal of the Fisheries Research Board of Canada 34:1670-1677.

Hartmann, J., and H. Quoss. 1993. Fecundity of whitefish (Coregonus lavaretus) during the eu- and oligotrophication of Lake Constance. Journal of Fish Biology 43:81-87.

Hatch, R. W., S. J. Nepszy, K. M. Muth, and C. T. Baker. 1987. Dynamics of the recovery of Western Lake Erie walleye (Stizostedion vitreum vitreum) stock. Canadian Journal of Fisheries and Aquatic Sciences 44 (Supplement 2):15-22.

Henderson, P. A., and W. G. R. Crampton. 1997. A comparison of fish diversity and abundance between nutrientrich and nutrient-poor lakes in the Upper Amazon. Journal of Tropical Ecology 13:175-198.

Herdendorf, E. 1983. Lake Erie water quality 1970-1982: a management assessment. CLEAR Technical Report No. 279. Center for Lake Erie Area Research, Columbus, Ohio, USA.

Hill, M. O. 1979. DECORANA-A Fortran program for detrended correspondence analysis and reciprocal averaging. Ecology and Systematics, Cornell University, Ithaca, New York, USA.

Hinch, S. G., N. C. Collins, and H. H. Harvey. 1991. Relative abundance of littoral zone fishes: biotic interactions, abiotic factors, and postglacial colonization. Ecology 72:1314-1324.

Holland, R. E. 1993. Changes in planktonic diatoms and water transparency in Hatchery Bay, Bass Island area, western Lake Erie since the establishment of the zebra mussel. Journal of Great Lakes Research 19:617624.

Huston, M. A. 1994. Biological diversity: the coexistence of species on changing landscapes. Cambridge University Press, Cambridge, Massachusetts, USA.

Hutchinson, G. E. 1961. The paradox of the plankton. American Naturalist 95:137-145.

Johnson, D. L. 1989. Lake Erie wetlands: fisheries considerations. Pages $257-273$ in K. A. Krieger, editor. Lake Erie estuarine systems: issues, resources, status, and management. National Oceanic and Atmospheric Administration, Estuarine Programs Office, Washington, D.C., USA.

Jongman, R. H. G., C. J. F. ter Braak, and O. F. R. van Tongeren. 1995. Data analysis in community and landscape ecology. Cambridge University Press, Cambridge, UK.

Jude, D. J., and J. Pappas. 1992. Fish utilization of Great Lakes coastal wetlands. Journal of Great Lakes Research 18:651-672.

Kay, R. F., R. H. Madden, C. Van Schaik, and D. Higdon. 1997. Primate species richness is determined by plant productivity: implications for conservation. Proceedings of the National Academy of Sciences (USA) 94:13023-13027.

Kershner, M. W., and R. A. Stein. 1998. Food web modeling in the western and central basins of Lake Erie. Federal Aid in Sport Fish Restoration, Project F-69-P, Final Report. Ohio Department of Natural Resources, Columbus, Ohio, USA.

Ketchum, B. H. 1969. Eutrophication of estuaries. Pages 197-209 in Eutrophication: causes, consequences, correctives. National Academy of Sciences, Washington, D.C., USA.

Knight, R. L., F. J. Margraf, and R. F. Carline. 1984. Piscivory by walleyes and yellow perch in western Lake Erie. Transactions of the American Fisheries Society 113:677-693.

Knight, R. L., and B. Vondracek. 1993. Changes in prey fish populations in western Lake Erie, 1969-88, as related to walleye, Stizostedion vitreum, predation. Canadian Journal of Fisheries and Aquatic Sciences 50:12891298.

Kremen, C. 1992. Assessing the indicator properties of species assemblages for natural areas monitoring. Ecological Applications 2:203-217.

Krieger, K. A., and L. S. Ross. 1993. Changes in the benthic macroinvertebrate community of the Cleveland harbor area of Lake Erie from 1978 to 1989. Journal of Great Lakes Research 19:237-249.

Krieger, K. A., D. W. Schloesser, B. A. Manny, C. E. Trisler, S. E. Heady, J. J. H. Ciborowski, and K. M. Muth. 1996. Recovery of burrowing mayflies (Ephemeroptera: Ephemeridae: Hexagenia) in western Lake Erie. Journal of Great Lakes Research 22:254-263.

Lake Erie Coldwater Task Group. 1998. Report of the Coldwater Task Group. Great Lakes Fishery Commission, Ann Arbor, Michigan, USA. 
Lake Erie Forage Task Group. 1999. Report of the Lake Erie Forage Task Group. Presented to the Lake Erie Committee. Ann Arbor, Michigan, USA.

Lang, C., and O. Reymond. 1996. Reversal of eutrophication in four Swiss lakes: evidence from oligochaete communities. Hydrobiologia 334:157-161.

Laws, E. A. 1981. Aquatic pollution, an introductory text. John Wiley and Sons, New York, New York, USA.

Leach, J. H., M. G. Johnson, J. R. M. Kelso, J. Hartmann, W. Nümann, and B. Entz. 1977. Responses of percid fishes and their habitats to eutrophication. Journal of the Fisheries Research Board of Canada 34:19641971.

Leach, J. H., and S. J. Nepszy. 1976. The fish community in Lake Erie. Journal of the Fisheries Research Board of Canada 33:622-638.

Leibold, M. A., J. M. Chase, J. B. Shurin, and A. L. Downing. 1997. Species turnover and the regulation of trophic structure. Annual Review of Ecology and Systematics 28:467-494.

Leonard, P. M., and D. J. Orth. 1986. Application and testing of an Index of Biotic Integrity in small, coolwater streams. Transactions of the American Fisheries Society 115:401-414.

Lubchenco, J. 1978. Plant species diversity in a marine intertidal community: importance of herbivore food preference and algal competitive abilities. American Naturalist 112:23-39.

Ludsin, S. A., K. A. Blocksom, and R. A. Stein. 1998. Species interactions among young-of-year fishes in Lake Erie. Federal Aid in Sport Fish Restoration Project Annual Performance Report F-69-P, FADR30. Ohio Department of Natural Resources-Division of Wildlife, Columbus, Ohio, USA.

Ludsin, S. A., and D. R. DeVries. 1997. First-year recruitment of largemouth bass: the interdependency of early life stages. Ecological Applications 7:1024-1038.

Lyons, J., L. Wang, and T. D. Simonson. 1996. Development and validation of an Index of Biotic Integrity for coldwater streams in Wisconsin. North American Journal of Fisheries Management 16:241-256.

Magnuson, J. J., and R. C. Lathrop. 1992. Historical changes in the fish community. Pages 193-231 in J. F. Kitchell, editor. Food web management: a case study of Lake Mendota. Springer-Verlag, New York, New York, USA.

Magurran, A. E. 1988. Ecological diversity and its measurement. Princeton University Press, Princeton, New Jersey, USA.

Makarewicz, J. C. 1993a. A lakewide comparison of zooplankton biomass and its species composition in Lake Erie, 1983-1987. Journal of Great Lakes Research 19:275-290.

Makarewicz, J. C. 1993b. Phytoplankton biomass and species composition in Lake Erie, 1970 to 1987. Journal of Great Lakes Research 19:258-274.

Makarewicz, J. C., and P. Bertram. 1991. Evidence for the restoration of the Lake Erie ecosystem. BioScience 41:216-223.

Maynard, L., and D. Wilcox. 1996. Great Lakes coastal wetlands. State of Lake Erie Conference (SOLEC) working paper, U.S. Environmental Protection Agency, Chicago, Illinois, USA.

McCune, B., and M. J. Mefford. 1995. PC-ORD: multivariate analysis of ecological data. Version 2.0. MjM Software Design, Gleneden Beach, Oregon, USA.

McIntosh, R. P. 1985. The background of ecology. Cambridge University Press, New York, New York, USA.

Meyer, J. L. 1997. Stream health: incorporating the human dimension to advance stream ecology. Journal of the North American Benthological Society 16:439-447.

Michigan Department of Natural Resources-Fisheries Division. 1996. Status of the fisheries in Michigan waters of Lake Erie and Lake St. Clair. Michigan Department of Natural Resources, Mt. Clemens, Michigan, USA.

Miner, J. G., and R. A. Stein. 1993. Interactive influence of turbidity and light on larval bluegill (Lepomis macrochirus) foraging. Canadian Journal of Fisheries and Aquatic Sciences 50:781-788.

Minns, C. K., V. W. Cairns, R. G. Randall, and J. E. Moore. 1994. An Index of Biotic Integrity (IBI) for fish assemblages in the littoral zone of the Great Lakes' areas of concern. Canadian Journal of Fisheries and Aquatic Sciences 51:1804-1822.

Naiman, R. J., J. J. Magnuson, D. M. McKnight, and J. A. Stanford. 1995. The freshwater imperative: a research agenda. Island Press, Washington, D.C., USA.

Nakashima, B. S., D. Gascon, and W. C. Leggett. 1977. Species diversity of littoral zone fishes along a phosphorusproduction gradient in Lake Memphremagog, Quebec-Vermont. Journal of the Fisheries Research Board of Canada 34:167-170.

Neilson, M., S. L'Italien, V. Glumac, D. Williams, and P. Bertram. 1995. Nutrients: trends and system response. State of Lake Erie Conference (SOLEC) working group paper, EPA 905-R-95-015. U.S. Environmental 
Protection Agency, Chicago, Illinois, USA.

Ney, J. J. 1996. Oligotrophication and its discontents: effects of reduced nutrient loading on reservoir fisheries. American Fisheries Society Symposium 16:285-295.

Nicholls, K. H., and G. J. Hopkins. 1993. Recent changes in Lake Erie (North Shore) phytoplankton: cumulative impacts of phosphorus loading reductions and the zebra mussel introduction. Journal of Great Lakes Research 19:637-647.

Nürnberg, G. K. 1995. The anoxic factor, a quantitative measure of anoxia and fish species richness in central Ontario lakes. Transactions of the American Fisheries Society 124:677-686.

O’Brien, W. J. 1987. Planktivory by freshwater fish: thrust and parry in the pelagia. Pages 3-16 in W. C. Kerfoot and A. Sih, editors. Predation: direct and indirect impacts on aquatic communities. University Press of New England, Hanover, New Hampshire, USA.

Ohio Department of Natural Resources-Division of Wildlife. 1997. Ohio's Lake Erie Fisheries, 1996. ODNR-ODW Sandusky, Ohio, USA.

Ontario Ministry of Natural Resources-Lake Erie Management Unit. 1999. Lake Erie Fisheries Report 1998. Queen's Printer for Ontario, Ontario, Canada.

Paine, R. T. 1966. Food web complexity and species diversity. American Naturalist 100:65-75.

Paller, M. H., M. J. M. Reichert, and J. M. Dean. 1996. Use of fish communities to assess environmental impacts in South Carolina Coastal Plain streams. Transactions of the American Fisheries Society 125:633-644.

Park, T. 1948. Experimental studies of interspecies competition. I. Competition between populations of the flour beetles Tribolium confusum Duval and Tribolium castaneum Herbst. Ecological Monographs 18:265-307.

Patalas, K. 1972. Crustacean plankton and the eutrophication of St. Lawrence Great Lakes. Journal of the Fisheries Research Board of Canada 29:1451-1462.

Persson, L., S. Diehl, L. Johansson, G. Andersson, and S. F. Hamrin. 1991. Shifts in fish communities along the productivity gradient of temperate lakes - patterns and the importance of size-structured interactions. Journal of Fish Biology 38:281-293.

Pianka, E. R. 1967. On lizard species diversity: North American flatland deserts. Ecology 48:333-351.

Ricciardi, A., F. G. Whoriskey, and J. B. Rasmussen. 1997. The role of the zebra mussel (Dreissena polymorpha) in structuring macroinvertebrate communities on hard substrata. Canadian Journal of Fisheries and Aquatic Sciences 54:2596-2608.

Robins, C. R., R. M. Bailey, C. E. Bond, J. R. Brooker, E. A. Lachner, R. N. Lea, and W. B. Scott. 1991. Common and scientific names of fishes from the United States and Canada. Fifth edition. American Fisheries Society, Bethesda, Maryland, USA.

Rodriguez, M. A., and W. M. Lewis. 1997. Structure of fish assemblages along environmental gradients in floodplain lakes of the Orinoco River. Ecological Monographs 67:109-128.

Rosa, F., and N. M. Burns. 1987. Lake Erie central basin oxygen depletion changes from 1929-1980. Journal of Great Lakes Research 13:684-696.

Rosenzweig, M. L., and Z. Abramsky. 1993. How are diversity and productivity related? Pages 52-65 in R. E. Ricklefs and D. Schluter, editors. Species diversity in ecological communities: historical and geographical perspectives. University of Chicago Press, Chicago, Illinois, USA.

Ruggiu, D., G. Morabito, P. Panzani, and A. Pugnetti. 1998. Trends and relations among basic phytoplankton characteristics in the course of the long-term oligotrophication of Lake Maggiore (Italy). Hydrobiologia 370:243-257.

Savino, J. F., and R. A. Stein. 1982. Predatory-prey interaction between largemouth bass and bluegills as influenced by simulated, submersed vegetation. Transactions of the American Fisheries Society 111:255-266.

Sommer, U., U. Gaedke, and A. Schweizer. 1993. The 1st decade of oligotrophication of Lake Constance. II. The response of phytoplankton taxonomic composition. Oecologia 93:276-284.

Sousa, W. P. 1979. Experimental investigation of disturbance and ecological succession in a rocky intertidal algal community. Ecological Monographs 49:227-254.

Stockner, J. G., E. Rydin, and P. Hyenstrand. 2000. Cultural oligotrophication: causes and consequences for fisheries resources. Fisheries 25:7-14.

Stuckey, R. L., and D. L. Moore. 1995. Return and increase in abundance of aquatic flowering plants in Put-In-Bay Harbor, Lake Erie, Ohio. Ohio Journal of Science 95:261-266.

Sweeney, R. A. 1993. "Dead" sea of North America?-Lake Erie in the 1960s and '70s. Journal of Great Lakes Research 19:198-199.

Tilman, D., and S. Pacala. 1993. The maintenance of species richness in plant communities. Pages 13-25 in R. E.

Ricklefs and D. Schluter, editors. Species diversity in ecological communities: historical and geographical 
perspectives. University of Chicago Press, Chicago, Illinois, USA.

Tonn, W. M., and J. J. Magnuson. 1982. Patterns in the species composition and richness of fish assemblages in northern Wisconsin lakes. Ecology 63:1149-1166.

Trautman, M. B. 1981. The fishes of Ohio. Ohio State University Press, Columbus, Ohio, USA.

Van Der Molen, D. T., R. Portielje, P. C. M. Boers, and L. Lijklema. 1998. Changes in sediment phosphorus as a result of eutrophication and oligotrophication in Lake Veluwe, the Netherlands. Water Research 32:32813288.

Verdonschot, P. F. M. 1996. Oligochaetes and eutrophication: an experiment over four years in outdoor mesocosms. Hydrobiologia 334:169-183.

Weisgerber, K. M. 2000. Lower trophic level dynamics in western basin, Lake Erie: changes in biomass, clearance, and nutrient excretion rates in crustacean zooplankton versus zebra mussels. Thesis. Ohio State University, Columbus, Ohio, USA.

Wetzel, R. G. 1983. Limnology. Second edition. Harcourt Brace College Publishing, New York, New York, USA.

Whittier, T. R., and R. M. Hughes. 1998. Evaluation of fish species tolerances to environmental stressors in lakes in the northeastern United States. North American Journal of Fisheries Management 18:236-252. 